\title{
Transaction
}

\section{Modification of Soybean Protein with Diisocyanates and Some Properties of the Modified Protein}

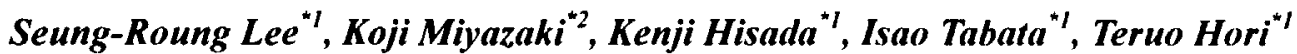 \\ "Faculty of Engineering, Fukui University, 3-9-1, Bunkyo, Fukui 910-8507, Japan \\ ${ }^{* 2}$ Industrial Technology Center of Fukui Prefecture, 61, Kawaiwashizuka-cho, Fukui 910-0102, Japan
}

\begin{abstract}
Soybean protein, as a vegetable protein, was modified by reacting it with a crosslinking agent, 2,4-tolylene diisocyanate. The molecular weights of modified soybean protein were increased as increasing the amount of added crossliking agent, but did not show the contents rate change of amino acid and sorption-desorption behavior of moisture by modification reaction, while the hydrophobicity of the proteins were increased with the progress of the modification reaction. The modified soybean proteins showed the good solubility in some polar organic solvents, especially in dimethylsulfoxide, when soybean protein $(3 \mathrm{~g})$ is modified with $7.5 \mathrm{mmol}$ TDI. It is interesting that the modified soybean proteins showed a plastic property and good affinity with polyacrylonitrile.
\end{abstract}

(Received 20 March, 2002; Accepted 22 August, 2003)

\section{Introduction}

Synthetic fibers have the excellent physical properties such as tensile strength, abrasion resistance, crease recovery and biological resistance. These fibers are a quite hydrophobic polymer and then the fibers show low moisture regain. That causes a number of problems in the application for the textile, such as the soiling, easy charging with electricity, slow soil removal and poor comfort [1].

To overcome the disadvantages of hydrophobic synthetic fibers, there were many attemps, for example, by mixing or grafting some hydrophilic second components in and on polymers [2-7]. Recently, it is also worth noting that there were some attemps to make up for these disadvantages, by binding the natural protein such as collagen [8], silk fibroin [9], keratin [10], sericin $[11,12]$ and gelatin [13] onto the synthetic fibers. Considering the fact that natural protein fibers such as silk and wool have many excellent properties, such as heat retainment, soft touch, moisture adsorption/release property, no static electricity. However, the supplement effect of disadvantages is not sufficient yet because of the low adhesion of natural protein on the fiber surfaces using some binders.

As an alternative method, applying natural proteins to overcome the disadvantages of synthetic fibers, we are planning to make natural feel fibers spun from the mixtures of synthetic polymers and natural proteins. On the other hand, it has been impossible to mix natural proteins with synthetic polymers because the natural proteins have generally poor solubility in appropriate organic solvents water and low heat stability and they have no melting property. Therefore, natural proteins need to be modified as to have considerable solubility in organic solvents, high thermal stability and melting property. Furthermore, considering practical applications, the common solvents of modified proteins and polymers must to be inexpensive and easily handled.

In a previous paper $[14,15]$, we have reported that animal proteins like egg white, milk whey, and gelatin became soluble in organic solvents such as a dimethylformamide (DMF) and dimethylacetamide (DMAc) because the molecular weight and surface hydrophobicity increase when they are crosslinked with 2,4-tolylene diisocyanate (TDI). We have also confirmed that the modified proteins maintained the excellent properties of the raw proteins.

Soybean protein, which is inexpensive and can be gotten large quantities, is composed of linear molecular of high molecular weight like a lot of petroleum polymer and estimated to have a good mechanical properties. In addition, the protein has several functional groups having good reactive properties, such as amino, hydroxyl, and carboxylic acid group. By chemical modification of these groups, it may be improved the each functional property, for example, adhesion, emulsion, physicochemical property. Therefore, it is taken notice of in each field, as an environmentally friendly material [16-20]. 
In this study, we attempt to modify soybean protein (SP) with hydrophobic bifunctional reagent, 2,4-tolylene diisocyanate (TDI), for the purpose of having solubility in organic solvents, higher thermal stability and some affinity against hydrophobic synthetic fibers. We also investigate that some chemical and physicochemical properties of modified soybean protein (mSP).

\section{Experimental}

\subsection{Materials}

Soybean Protein as vegetable protein was purchased as powder form from ICN Biomedicals, Inc. All other reagents were available commercially and were used without further purification.

\subsection{Modification of soybean protein}

As a crosslinking agent for modification of SP, 2,4-tolylene diisocyanate (TDI) was chosen. SP (3 g) was dissolved in $300 \mathrm{ml} \mathrm{NaOH}$ aqueous solution ( $\mathrm{pH} \mathrm{12}$ ) and in order to improve the solubility of the protein in water and the reactivity of amino groups with crosslinking agent. The solution was stirred for $24 \mathrm{~h}$ at $20{ }^{\circ} \mathrm{C}$. On the other hand, to obtain the modified proteins with different degree of crosslinking, $1 \mathrm{mmol}$ to $15 \mathrm{mmol}$ of TDI was dissolved in $13.5 \mathrm{ml}$ chloroform. Then the TDI solution was added to the aqueous protein solution. The emulsified solution was stirred vigorously with mechanical stirrer for $3 \mathrm{~h}$ at $50{ }^{\circ} \mathrm{C}$. After the crosslinking reaction the emulsified solution was held at room temperature for $6 \mathrm{~h}$, to be separated into water and chloroform layer. The chloroform phase was removed. When the $\mathrm{pH}$ of the aqueous layer was adjusted around the isoelectric point of SP ( $\mathrm{pH} \mathrm{4.0)}$ with citric acid, the crosslinked protein was precipitated. It was then centrifugal filtered at 4,000 rpm. and freeze-dried.

Crosslinking reaction of SP with TDI was monitored by the UV absorbance of the aqueous layer at $250 \mathrm{~nm}$, which is absorption maximum of TDI.

\subsection{Measurements}

\subsubsection{Acid-base titration of proteins}

$0.5 \mathrm{~g} / 50 \mathrm{ml} \mathrm{SP}$ and $\mathrm{mSP}$ dissoived for $3 \mathrm{~h}$ in $1 \mathrm{~N}$ $\mathrm{NaOH}$ aqueous solution were titrated with $1 \mathrm{~N} \mathrm{HCl}$ at 20 ${ }^{\circ} \mathrm{C}$.

\subsubsection{Molecular weight}

Molecular weight of proteins was measured by SEC (Tosoh HPLC model 8010). The eluting solution was $50 \mathrm{mM}$ phosphate $\mathrm{pH} 7$ buffer solution including $0.3 \mathrm{M}$ $\mathrm{NaCl}$ and flow rate was $1 \mathrm{ml} / \mathrm{min}$. The column used was TSK gel G 2000 SWXL and TSK gel G 3000 SWXL. Detection was carried out at $280 \mathrm{~nm}$ which was the protein's own peculiar absorbance peak.

\subsubsection{Amino acid content}

Amino acid content of SP and mSP was determined by usual method using a Hitachi amino acid analysis system L-8500.

\subsubsection{Solubility}

Solubility of proteins in the three organic solvents, which are dimethylsulfoxide (DMSO), dimethylacetamide (DMAc), dimethylformamide (DMF) and in water were evaluated as turbidity by measuring optical density of $1 \mathrm{wt} \%$ or $0.5 \mathrm{wt} \%$ protein solution at $600 \mathrm{~nm}$. Before measurements, each protein sample was put in organic solvents mentioned above or water, stirred for $12 \mathrm{~h}$ at $50{ }^{\circ} \mathrm{C}$.

\subsubsection{Moisture adsorption/desorption}

The protein powder was first dried absolutely and was placed in a humidifier of $95 \% \mathrm{RH}$ and $30{ }^{\circ} \mathrm{C}$. The weight change of the powder was followed for $1 \mathrm{hr}$. After that the powder was moved to dry state in a conditioning room of $38 \% \mathrm{RH}$ and $23{ }^{\circ} \mathrm{C}$ for $1 \mathrm{hr}$. The weighting of powder was performed per 5 minutes. The adsorption and desorption measurement was repeated several times.

\subsubsection{Thermal property}

Thermal property of protein samples was measured with differential scanning calorimeter (Seiko Instruments \& Electric Co., LTD. SSC-580/DSC-20). The temperature readings were calibrated with a standard indium. Ca. $5 \mathrm{mg}$ of samples were dried under vacuum, put into an aluminum pan per each and the pan was sealed completely. The first heating run was preformed just to remove a trace amount of water $\left(20{ }^{\circ} \mathrm{C} / \mathrm{min}\right.$, $30-110{ }^{\circ} \mathrm{C}$, holding $30 \mathrm{~min}$ ). After the sample was quenched with liquid nitrogen, the second heating run was operated at a heating rate of $5{ }^{\circ} \mathrm{C} / \mathrm{min}$ in the temperature range $30^{\circ} \mathrm{C}$ to $350{ }^{\circ} \mathrm{C}$.

It was observed the affinity of the membranes of polyacrylonitrile (PAN) and $\mathrm{mSP}$ by the almost same method above except the second heating rate $\left(10^{\circ} \mathrm{C} / \mathrm{min}\right)$.

\section{Results and discussion}

In the reaction of protein and TDI in alkali condition, the isocyanate group in TDI can react with free amino groups and hydroxyl groups of the protein to form the urea bond and the urethane bond, respectively. And also there is a possibility that some isocyanate groups of TDI remained unreacted. In our study, an excess of TDI was used as compared with the amount of free amino groups and hydroxyl groups of protein, because TDI can react 
with water molecule too.

Fig. I shows the UV absorption spectra of aqueous phase in the SP/TDP $(3 \mathrm{~g} / 7.5 \mathrm{mmol})$ reaction system as a function of reaction time. The aqueous solution was diluted with water to one four-hundredth of its initial concentration for the spectroscopic measurement. Before the reaction, there was no peak at $250 \mathrm{~nm}$, corresponding to the maximum absorption of TDI. On the other hand, the O.D at this wavelength increased with reaction time up to $I \mathrm{~h}$. From this spectra change, we could consider that TDI was introduced in SP during the reaction and the reaction is finished in ca. $1 \mathrm{~h}$. The yield of modified soybean protein is about $75-85 \%$.

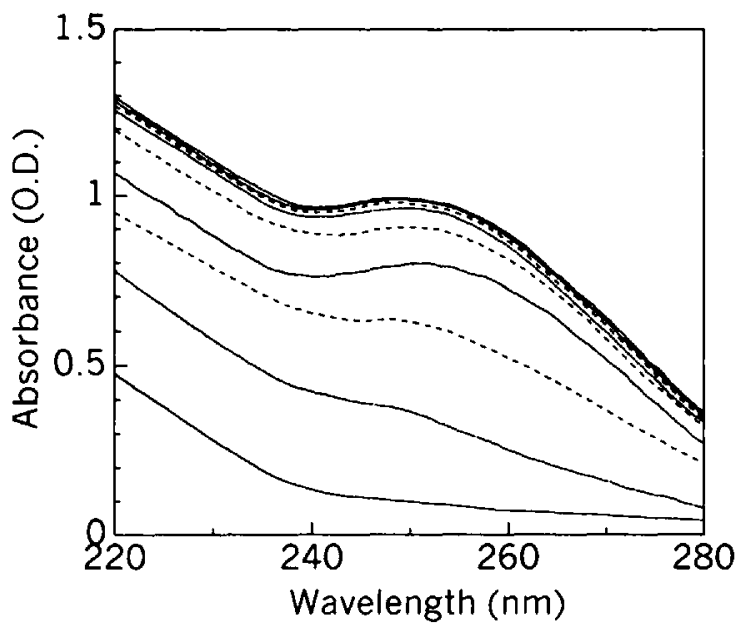

Fig. 1 UV absorption spectra of the water phase solution diluted to one four hundredth in the soybean protein /TDI $(3 \mathrm{~g} / 7.5 \mathrm{mmol})$ reaction system at various reaction time : from bottom ; $0,5,10,20$, $30,50,60,120$, and $180 \mathrm{~min}$

Fig. 2 shows the acid/base titration curves of SP and mSP prepared from SP/TDI $(3 \mathrm{~g} / 7.5 \mathrm{mmol})$ solution. The dissociation constants $\mathrm{pKa} 2$, corresponding to the dissociation of carboxyl groups of $\mathrm{SP}$ and $\mathrm{mSP}$ were approximately same $(\mathrm{pKa} 2 \cdot \mathrm{SP}=5.7, \mathrm{pKa} 2 \cdot \mathrm{mSP}=5.3)$. It suggests that the amount of carboxyl groups in SP did not change during the crossliking reaction. On the other hand, the value of pKal, corresponding to the dissociation of amino groups of SP and $\mathrm{mSP}$ were 4.4 and 2.9 , respectively. This means that although the amount of free amino groups in SP decreased by crossliking, a large number of free amino groups still exist in $\mathrm{mSP}$. From this result, $\mathrm{mSP}$ seems to retain the same properties of its raw protein as like hydrophobic and hydrophilic properties. In addition, isoelectric point (pI) of $\mathrm{mSP}$ calculated according to the relation $\mathrm{pl}=$ $(\mathrm{pKal}+\mathrm{pKa} 2) / 2$ was 4.1 . This was in accord with the

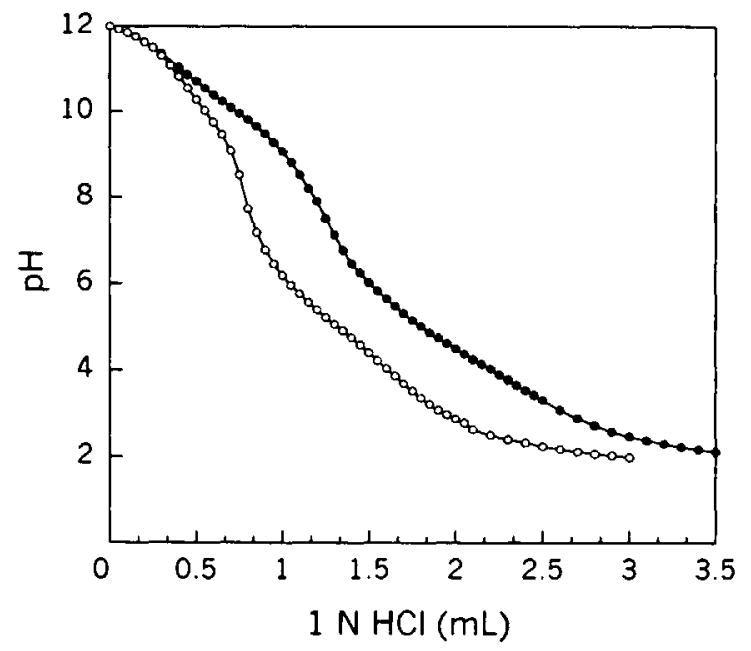

Fig. 2 Acid/base titration curve of soybean protein (SP) and modified SP prepared from SP/TDI $(3 \mathrm{~g} / 7.5$ mmol) solution : SP $(O) ; \operatorname{mSP}(O)$

$\mathrm{pH}$, at which the product had precipitated from aqueous phase after crosslinking reaction.

The dependence of molecular weights of modified soybean protein on the TDI concentration is shown in Fig. 3. The molecular weight of modified proteins increased with the TDI concentration. TDI molecules were not only crosslink more than two protein molecules, but also reacted with only one amino or hydroxyl group. In the later case, another isocyanate group can react with water to produce carbamic acid group, which decarboxylate with extreme ease to give an amino group.

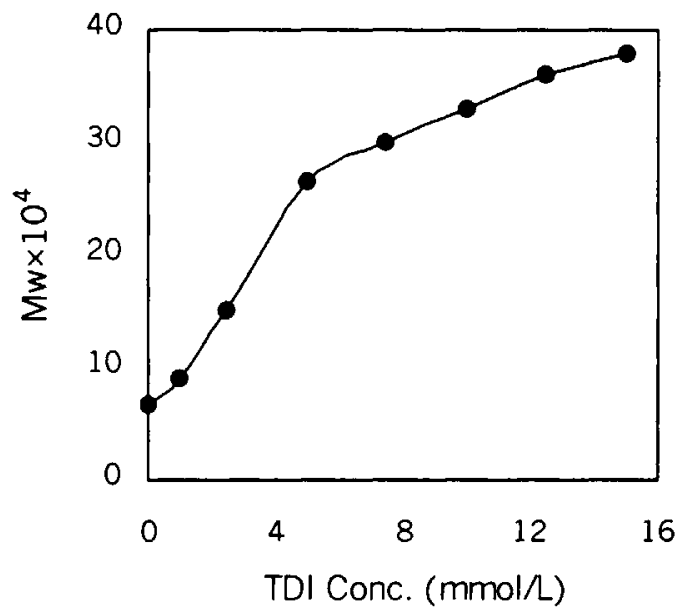

Fig. 3 The relation between TDI concentration and molecular of modified soybean protein

Fig. 4 shows the content of amino acid (a) and their ratio (b) in $1 \mathrm{~g} \mathrm{SP}$ and $\mathrm{mSP}$. It can be concluded that $\mathrm{mSP}$ consisted of ca. $69.5 \mathrm{wt} \%$ amino acid and ca. 30.5 $w t \%$ TDI from the result that each amino acid contents of $\mathrm{mSP}$ was ca. $30.5 \mathrm{wt} \%$ lower than that of SP. On the 
other hand, the ratio of each amino acid content against total amino acid content was almost the same as that of raw proteins. Thereby $\mathrm{mSP}$ is expected to have the characteristic properties of its raw SP.

16
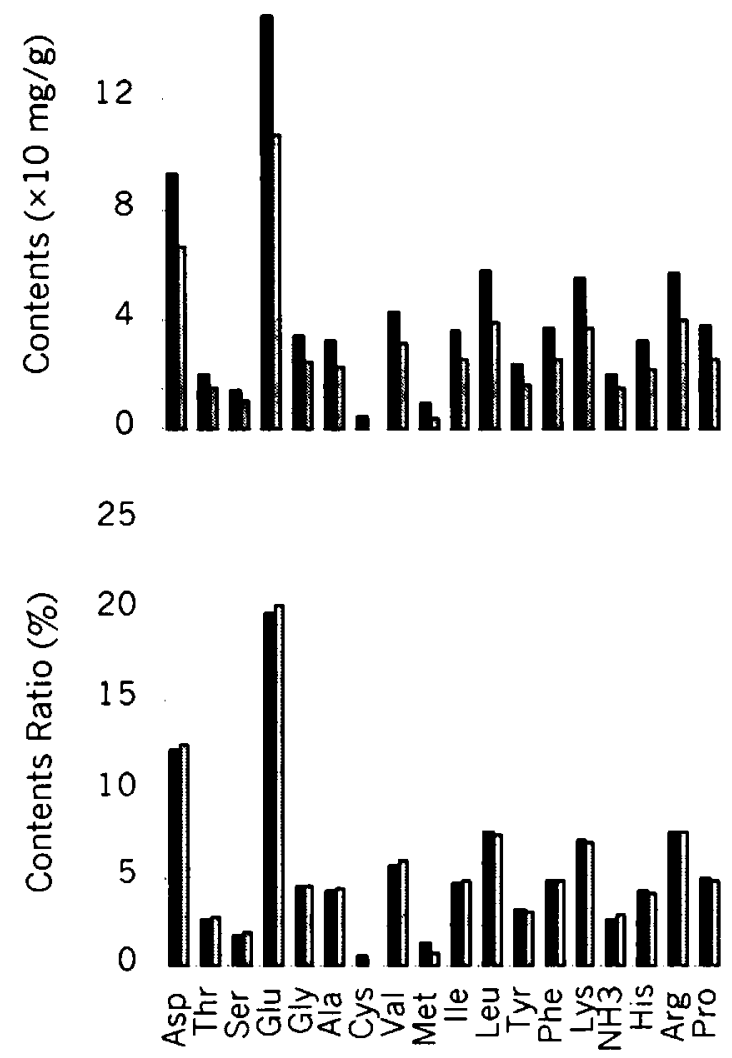

Fig. 4 Amino acid content (a) and content ratio (b) of SP and $\mathrm{mSP}$ prepared from SP/TDI $(3 \mathrm{~g} / 7.5 \mathrm{mmol})$ reaction solution : $\mathrm{SP}(\boldsymbol{\square}) ; \operatorname{mSP}(\square)$

Fig. 5 shows the turbidity of $\mathrm{mSP}$ in the several organic solvents. When $3 \mathrm{~g} \mathrm{SP}$ was modified with 7.5 mmol TDI, the mSP showed a good solubility. The solution became turbid when SP was modified with TDI higher or lower than $7.5 \mathrm{mmol}$. DMSO is best solvent for $\mathrm{mSP}$ among DMSO, DMAc and DMF. The DMSO solution of $\mathrm{mSP}$ was transparent but weakly yellowish. As the two other solutions did not clear as the DMSO solution, the two solvents are less proper for a solvent of $\mathrm{mSP}$. From this results, we can know that soybean protein is demanded to react with ca. $2.4 \mathrm{mmol} / \mathrm{g}$ TDI in order to achieve the best solubility in DMSO.

Fig. 6 shows the change of solubility of SP and $\mathrm{mSP}$ in DMSO and in water with different $\mathrm{pH}$ value. In the case of DMSO, the solubility was measured by adding a buffer solution to a DMSO solution of the modified soybean protein. The represented $\mathrm{pH}$ means the $\mathrm{pH}$ value of the added aqueous solution. The natural SP was insoluble in DMSO at all, but soluble in water in all $\mathrm{pH}$ range besides $\mathrm{pH} 3-5$, which was in accord with that isoelectric point (about 5.0) of SP (Fig. 2). While due to the modification, the modified protein $\mathrm{mSP}$ was soluble in DMSO below $\mathrm{pH} 5$ as well as in water above $\mathrm{pH} 6$.

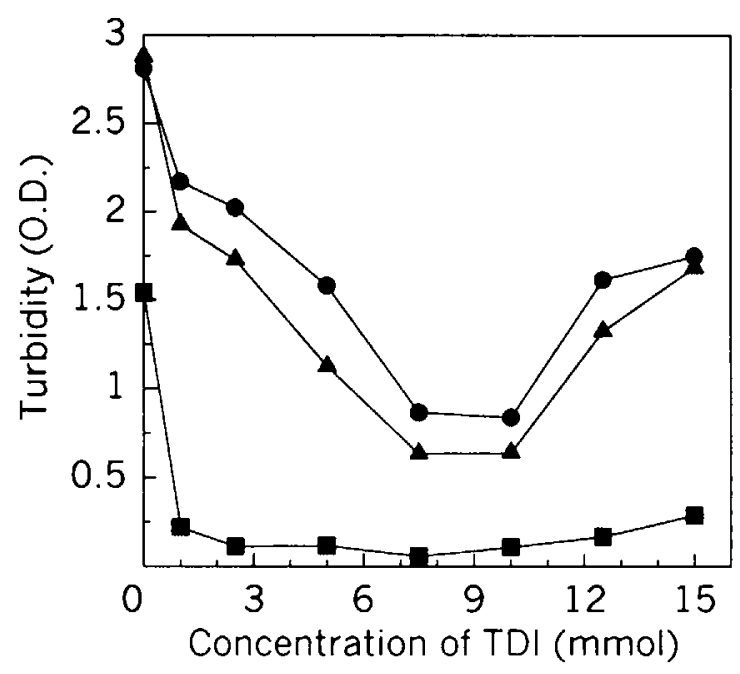

Fig. 5 Turbidity of 1 wt $\%$ modified soybean protein ( $\mathbf{\square}: \mathrm{DMSO}, \mathbf{A}: \mathrm{DMAc}, \mathrm{DMF})$

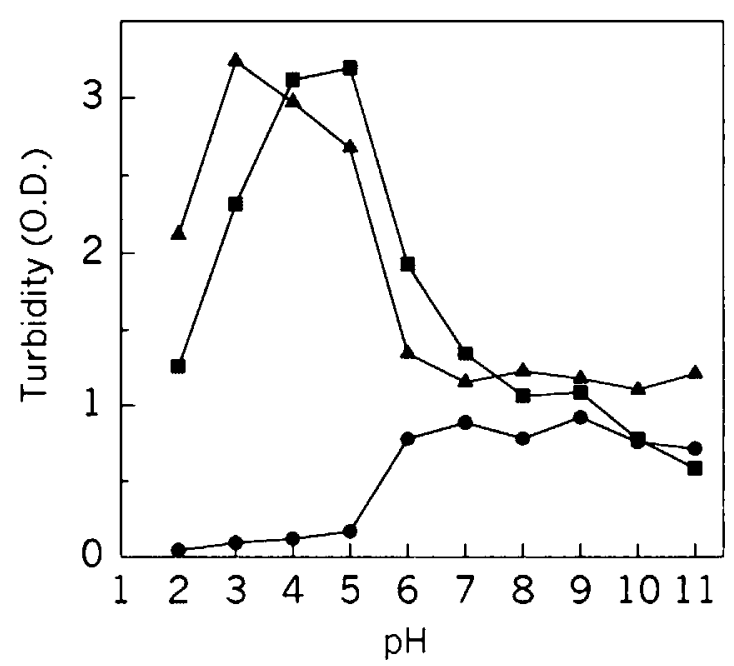

Fig. 6 The Solubility of SP and $\mathrm{mSP}$ prepared from 0.5 $w t \%$ SP/TDI ( $3 \mathrm{~g} / 7.5 \mathrm{mmol}$ ) solution in DMSO and in water at various $\mathrm{pH}: \mathrm{mSP}$ in DMSO (O); $\mathrm{mSP}$ in water (A): SP in water ( $\mathbf{0})$

Fig. 7 shows the adsorption and desorption properties of moisture on soybean protein and modified soybean protein prepared from SP/TDI $(3 \mathrm{~g} / 7.5 \mathrm{mmol})$ from dry state $\left(\mathrm{RH} 38 \%, 23{ }^{\circ} \mathrm{C}\right)$ to wet state (RH $95 \%, 30^{\circ} \mathrm{C}$ ).

From the fig. 7 , we can know that the sorption and desorptin property of $\mathrm{SP}$ and $\mathrm{mSP}$ is almost same tendency. The sorption rate of $\mathrm{mSP}$ is lower than that of 
$\mathrm{SP}$. The reason is that $\mathrm{mSP}$ is crosslinked with TDI, hydrophobic material, and then become to be more hydrophobic than the unmodified protein.

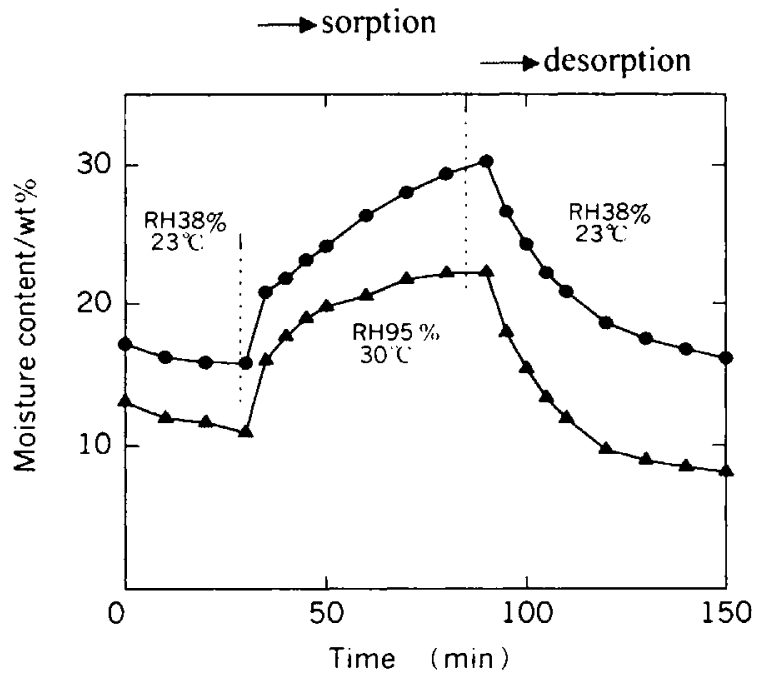

Fig. 7 sorption-desorption behavior of moisture for $\mathrm{SP}(\mathbf{O})$ and $\mathrm{mSP}(\boldsymbol{\Delta})(3 \mathrm{~g} / 7.5 \mathrm{mmol})$

Fig. 8 shows the DSC thermograms of SP and $\mathrm{mSP}$. In the case of SP, the degradation is finished about 208 ${ }^{\circ} \mathrm{C}$, even though the starting degradation temperature degree is not clear. On the other hand, it should be noted endothermic peak in the case of $\mathrm{mSP}$ is appeared between 230 and $250{ }^{\circ} \mathrm{C}$ according to increase of TDI amount. It was well known that general protein was not shown the melting point and carbonized by heating. From this result, it considered that the endothermic peak

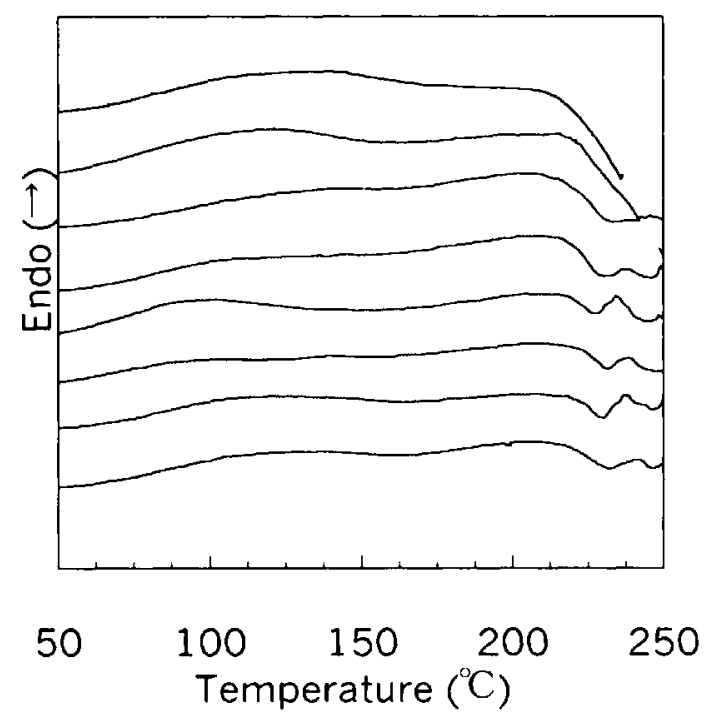

Fig. 8 DSC thermograms of soybean protein and modified proteins : from top $0,1,2.5,5,7.5,10$, $12.5,15 \mathrm{mmol}$ of TDI against $3 \mathrm{~g}$ soybean might be due to melting behavior of modified proteins that was provided by modification making SP possess certain hydrophobicity and below $\mathrm{Tg}$ point. This was supported by the observation the specimens after second heat (see Fig. 9). As shown in Fig. 9, the heated mSP showed luster while SP was looked like soot after the thermal treatment. Therefore, we may conclude that mSP has not only protein's own property but also plastic property.

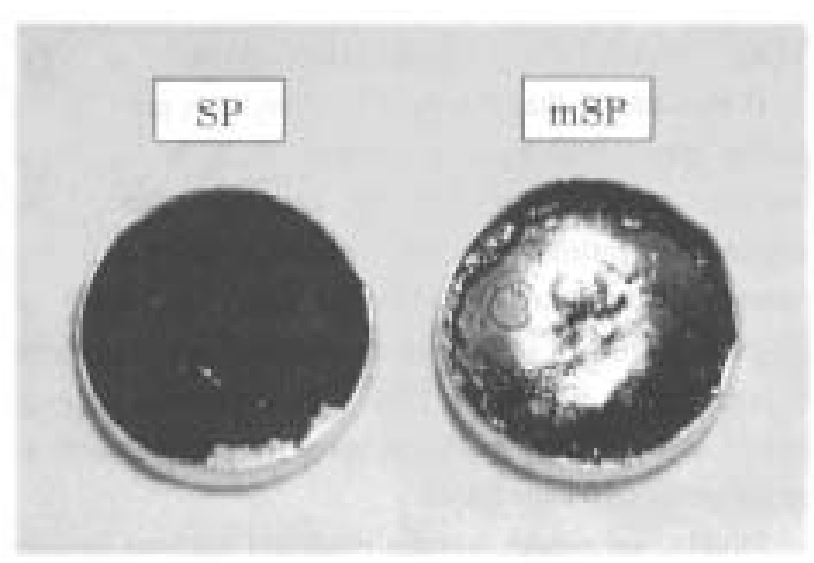

Fig. 9 Photographs of proteins after heating up to $350^{\circ} \mathrm{C}$ in DSC pans

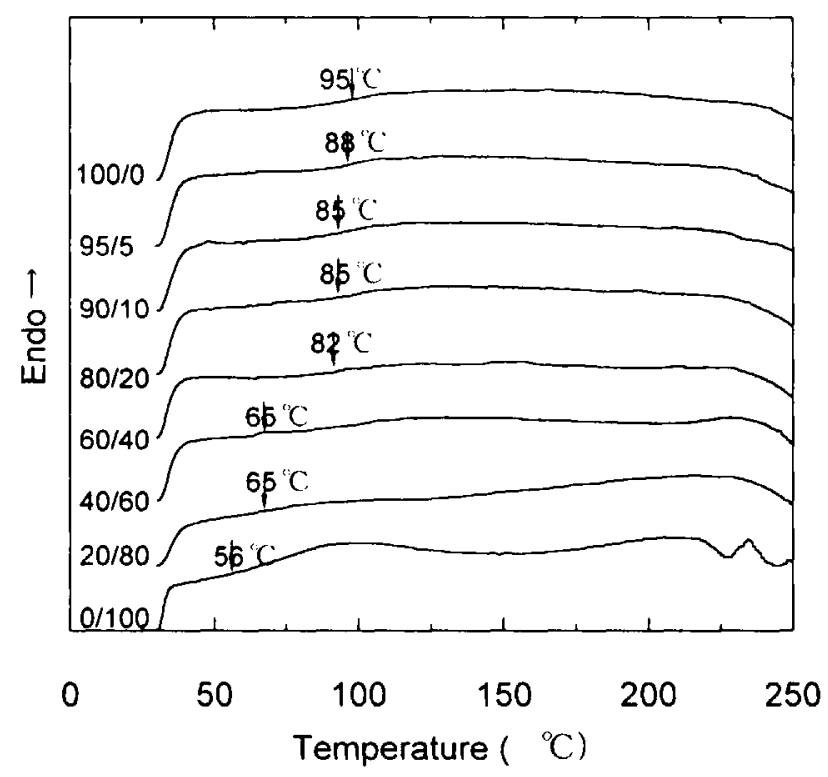

Fig. 10 DSC charts of PAN $/ \mathrm{mSP}$ blend membranes.

Numbers on curves show mixing ratio of $\mathrm{PAN} / \mathrm{mSP}$

Fig. 10 shows the DSC curves for PAN/mSP blend membranes. The membranes were prepared by casting from the DMSO solution and drying them in vacuo. 
As the content rate of $\mathrm{mSP}$ is increasing, the blend membranes $\mathrm{Tg}$ are approached to the $\mathrm{Tg}$ of $\mathrm{mSP}$. From this fact, it is considered that the excellent affinity shows beween PAN and $\mathrm{mSP}$.

\section{Conclusion}

In this paper, it was successful to make soybean protein soluble in organic solvents by reacting with hydrophobic crosslinking agent 2,4-tolylene diisocyanate (TDI).

It was found that the modified soybean protein had similar physicochemical properties, such as acid/bace titration curve, amino acid contents ratio, and sorption-desorption behavior, with soybean protein and became to be soluble in DMSO easily as molecular weight is increased and proper hydrophobicity was added by crosslinking bond with TDI. The modified soybean protein also showed a plastic property and showed an excellent affinity with PAN.

Finally, we expect that the modified soybean protein could be utilized as a substitute for petroleum materials.

\section{References}

1. S. Ooya, Y. Muraoka, "Sinsen 'igenryogaku", Aikawa, p.15 (1980).

2. J. Chen and N. Minoura, Polymer, 35, 2853 (1994).

3. S. Mizutani, A. Takizawa, T. Kinishita, and Y. Tsujita, Text. Res. J., 56, 347 (1986).

4. M. Maeda, M. Kimura, Y. Hareyama, and S. Inoue, J. Am. Chem. Soc., 106, 250 (1984).

5. M. Maeda, M. Aoyama, and S, Inoue, Makromol, Chem., 187, 2137 (1986).
6. D. W. Chung, S. Higuchi, M. Maeda, and S. Inoue, $J$. Am. Chem. Soc., 108, 5823 (1986).

7. K. Suzuki, I. Kido and N. Tanabe, Sen'I Gakkaishi, 28, 343 (1972).

8. M. Yamada, K. Tamahisa, and T. Hagiwara. JA. Pat. No. 09228249 Kurashiki Spining Co.

9. T. Tabata, S. Takeuchi, and A. Katagiri. JA. Pat. No. 07300772 Shinano Kenshi Co.

10. D. E. Rivett, Text. Res. J., 63, 109 (1993).

11. P-Z. Ji, T. Igarashi. and T. Hori, Japan Sen'i Kogyo Kenkyu Gyokai Hokoku, 3, 44 (1993).

12. H. Kato and K. Yasuta, Nippon Sanshigaku Zasshi, 68, 73 (1999).

13. H. S. Ryu and J. M. Park, KR. Pat. No. 9513036.

14. K. Yamkoshi, J. C. Park, and T. Hori, Sen'l Gakkaishi, 51, 544 (1995).

15. J.C. Park, T.Yamaguchi, and T. Hori, Text. Res. J., 68, 127 (1998)

16. M. Kito, T. Moriyama, Y. Kimura and H. Kambara, Biosci Biotech Biochem, 57, 354 (1993).

17. S. Utsumi, AB. Gidamis, B. Mikami and M. Kito, Escherichia soli. J. Mol Biol, 233, (1993).

18. S. Utsumi, AB. Gidamis, Y. Takenaka, N. Maruyama, M. Adachi and M. Mikami, In : Macromolecular Interactions in Food Technology, ASC Symposium Series 650, N. Parris, A. Kato, LK. Creamer and J. Pearce, eds., American Chemical Society, Washington DC, 257 (1996).

19. C. S. Kim, S. Kamiya, J. Kanamori, S. Utsumi and M Kito, Escherichia coli. Agric Biol Chem, 54, 1543 (1990).

20. AT. Brüger, J. Kuriyan and M. Karplus, Science, 35, 458 (1987) 